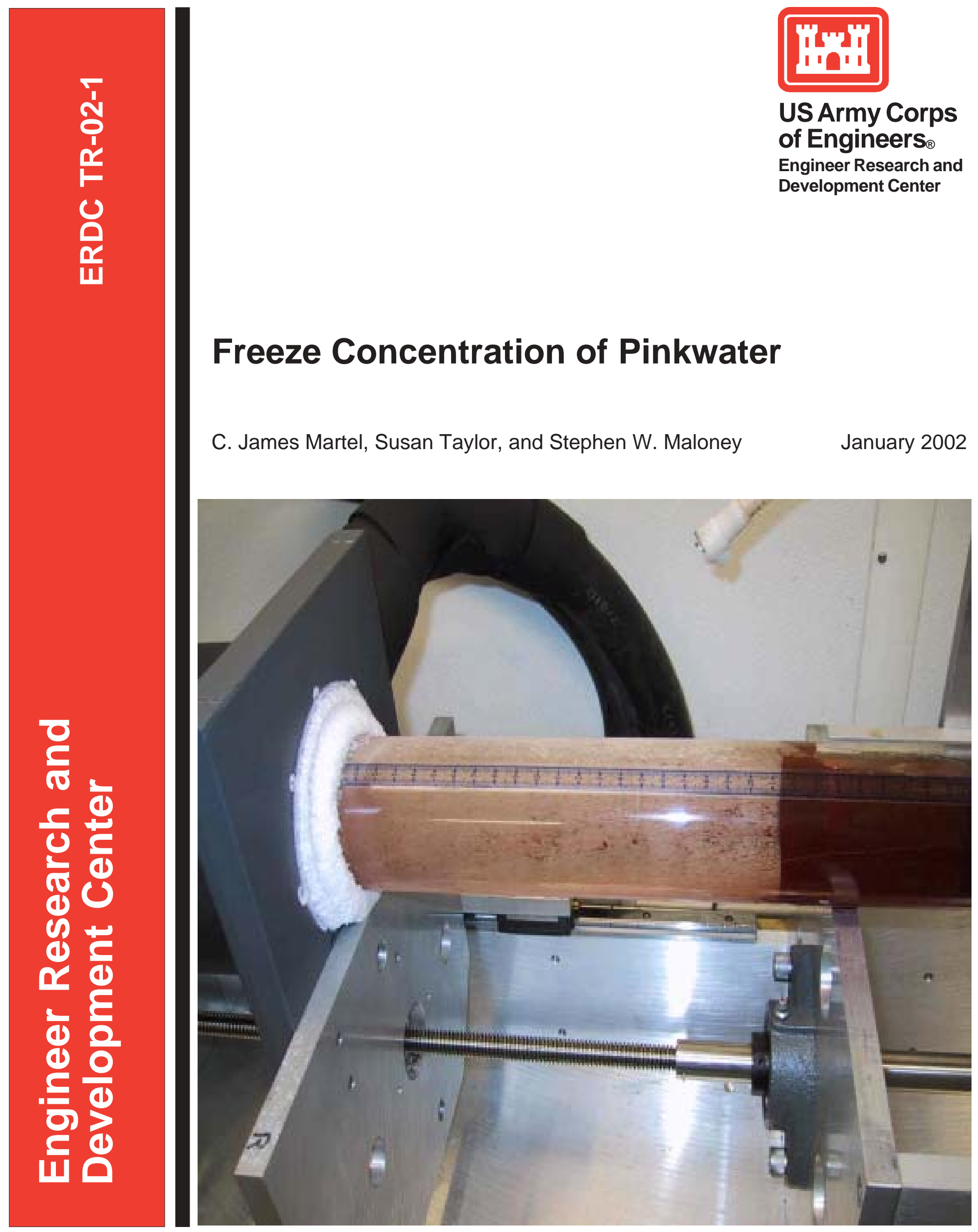


Abstract: The freeze concentration process was evaluated as a method of concentrating munitions wastes. A bench-scale study was conducted at the U.S. Army Cold Regions Research and Engineering Laboratory (CRREL) using pinkwater obtained from McAlester Army Ammunition Plant (AAP) in McAlester, Oklahoma. A special apparatus was constructed that allowed a sample to be frozen at a constant freezing rate. Six runs were conducted at different freezing rates. The results of this study show that the freeze concentration process is capable of meeting a $1.0 \mathrm{mg} / \mathrm{L}$ TNT discharge permit limit in the meltwater. However, the rate of freezing must be very slow to meet this criterion. An alternative would be to conduct multi-stage freezing at a higher freezing rate. Calculations show that the TNT limit could be achieved in six freezing cycles at $10 \mathrm{~mm} / \mathrm{hr}$.

COVER:

Plexiglas cylinder after freeze concentration of pinkwater during Run \#2. Note the relatively clear ice cylinder on the left and the darker concentrate on the right.

\footnotetext{
tion Center:

DTIC-BR SUITE 0944

8725 JOHN J KINGMAN RD

FT BELVOIR VA 22060-6218

Telephone (800) 225-3842

E-mail help@dtic.mil msorders@dtic.mil

WWW http://www.dtic.mil/
}

How to get copies of CRREL technical publications:

Department of Defense personnel and contractors may order reports through the Defense Technical Informa-

All others may order reports through the National Technical Information Service:

NTIS

5285 PORT ROYAL RD

SPRINGFIELD VA 22161

Telephone (703) 487-4650

(703) 487-4639 (TDD for the hearing-impaired)

E-mail_orders@ntis.fedworld.gov

WWW http://www.ntis.gov/index.html

A complete list of all CRREL technical publications is available from USACRREL (CEERD-IM-HL)

72 LYME RD

HANOVER NH 03755-1290

Telephone (603) 646-4338

E-mail_erhoff@crrel.usace.army.mil

For information on all aspects of the Cold Regions Research and Engineering Laboratory, visit our World Wide Web site: 


\section{Technical Report ERDC TR-02-1}

\section{Freeze Concentration of Pinkwater}

C. James Martel, Susan Taylor, and Stephen W. Maloney

January 2002 


\section{PREFACE}

This report was prepared by C. James Martel, Environmental Engineer, Applied and Military Engineering Branch, and Susan Taylor, Research Physical Scientist, Environmental Sciences Branch, U.S. Army Engineer Research and Development Center (ERDC), Cold Regions Research and Engineering Laboratory (CRREL), Hanover, New Hampshire; and by Stephen W. Maloney, Environmental Engineer, Environmental Processes Branch, ERDC, Construction Engineering Research Laboratory (CERL), Champaign, Illinois.

Funding for this research was provided by BT-25, Environmental Quality Basic Research Program.

The authors thank Scott F. Sullivan, Water Program Manager, McAlester Army Ammunition Plant, for providing pinkwater samples and moral support for this project.

This publication reflects the personal views of the author and does not suggest or reflect the policy, practices, programs, or doctrine of the U.S. Army or Government of the United States. The contents of this report are not to be used for advertising or promotional purposes. Citation of brand names does not constitute an official endorsement or approval of the use of such commercial products 


\section{CONTENTS}

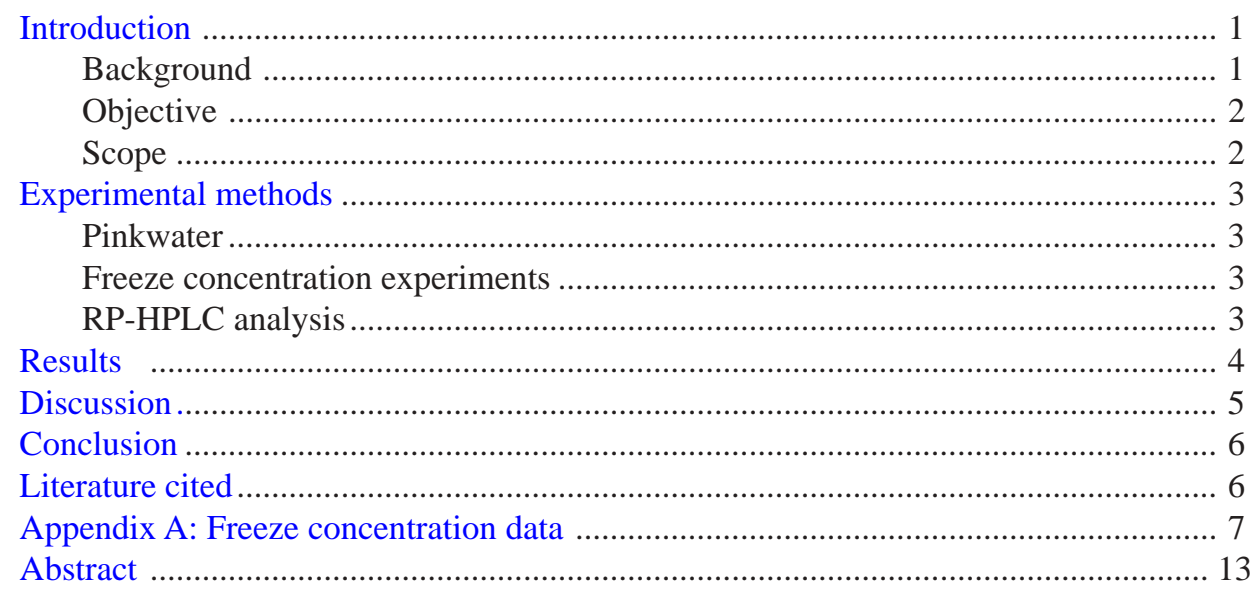

\section{ILLUSTRATIONS}

Figure

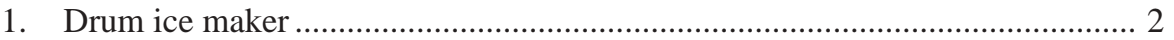

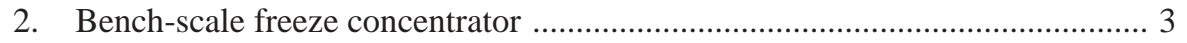

3. Visual comparison of ice cylinder color and clarity. ........................................ 4

4. TNT concentration in ice cylinder at each freezing rate ................................... 5

5. RDX concentration in ice cylinder at each freezing rate ................................. 5

6. Effect of freezing rate on average TNT concentration in ice column ............... 5

7. Entrapment coefficients for TNT and RDX as a function of freezing rate ....... 6

\section{TABLES}

Table

1. Conditions during freeze concentration experiments ........................................ 3

2. Concentrations of TNT and RDX in residuals .............................................. 5 


\title{
FREEZE CONCENTRATION OF PINKWATER
}

\author{
C. JAMES MARTEL, SUSAN TAYLOR, AND STEPHEN W. MALONEY
}

\section{INTRODUCTION}

\section{Background}

Army industrial operations, such as munitions production and demilitarization, generate large volumes of hazardous wastes. A single Army Ammunition Plant (AAP) can discharge as much as 500,000 gallons of wastewater per day. Untreated discharges and solid wastes have contaminated billions of tons of soil as well as the underlying groundwater. Currently, 20 Army Ammunition Plants have TNT-contaminated soil or groundwater, and 10 are on the National Priority List (NPL) (Painter 1996). Also of concern at Operations Support Command (OSC) facilities are new water quality standards and revised permit limits. Most of these treatment facilities are 30-50 years old. If industrial wastes continue to be discharged to these plants, they may not be able to meet these standards. New pretreatment technologies will be required at many of these installations to facilitate compliance.

According to information posted on the U.S. Army Environmental Requirements Technology Assessment (AERTA) Web site (http://aec.army.mil/prod/usaec/et/ aerta.htm), the cost of Army projects related to treatment of wastewater from munitions in FY 97 was over $\$ 11 \mathrm{M}$. The total cost of treatment, monitoring, and control of Army wastewater, including plating wastes, is over $\$ 253 \mathrm{M}$.

One way to reduce disposal costs is to reduce the amount of wastes generated by removing some of the water. Conventional methods of separation, such as sedimentation and filtration, are only partially successful because the munitions compounds are mostly dissolved in water and thus cannot settle out or be filtered out. Evaporation is not attractive for munitions production and demilitarization wastes because they are explosive and flammable.
The freeze concentration process has the potential to overcome these difficulties. This method is used in the food industry for concentrating milk, fruit juices, beer, wine, and other food products (EPRI 1987). It has long been the technology of choice in the food industry because it uses less energy than evaporation and it produces a purer product. Freeze concentration may also provide a method of treating redwater and ammonium perchlorate. Present methods, such as the use of granular activated carbon, are unable to treat these wastes.

Once most of the water is removed, the cost of disposal is significantly reduced. For example, plasma arc vitrification has been proposed as a treatment for many wastes. By removing most of the water by freeze concentration, most of the plasma energy would be used to oxidize organic matter and vitrify metals rather than evaporate water. Removing water has the secondary effect of reducing off-gases, whether plasma arc or conventional incineration is used. Another treatment option would be to discharge the concentrate to drying lagoons as is done with demilitarization wastewaters. Removing most of the water by freeze concentration would reduce the land area required for the lagoons.

A bonus benefit of the freeze concentration process is central air conditioning of facilities. The ice can be stored and used in conjunction with a heat pump to produce cooling energy. Savings range from $30 \%$ to $70 \%$ over conventional air conditioning depending on location and use of off-peak power (Integrated-Ice Systems, Inc. 1999). This benefit would be a boon to most Army Ammunition Plants located in warm climates.

The mechanism of freeze concentration is a physical process whereby water is separated from impurities during the formation of ice crystals. As explained by Glen (1974), ice is a solid that consists of a crystal- 
lographic arrangement of water molecules. These water molecules are bonded together by the positive charge concentrations of one molecule in contact with the negatively charged concentrations of another. This purely electrostatic attraction between charged concentrations is very strong and plays a major role in organizing the structure of the ice crystal. Because of this strong attraction, other molecules or particles cannot become part of the ice crystal lattice and are rejected. As a result, suspended and dissolved solids are rejected by growing ice crystals that are made up of water molecules only. Any non-water molecules are displaced into voids between ice crystals or into the concentrated solution ahead of the freezing front. The amount of non-water molecules displaced into voids depends on the rate at which the solution is frozen. Flash-frozen ice contains approximately the same concentration of non-water molecules as the parent solution, so no freeze concentration takes place. Conversely, ice frozen at a slow freezing rate contains almost no non-water molecules. For practical purposes, the desired degree of displacement lies somewhere between these two extremes. To complete the concentration process, the ice must be thawed and the meltwater removed by draining or decanting.

Freeze concentration of dissolved impurities can be accomplished by two techniques: freeze crystallization and progressive freezing. In freeze crystallization, the solution is mixed during freezing. This procedure forms slurries consisting of ice crystals and concentrate. The slurry is then pumped to a wash column where the crystals are washed with pure water. Because of the high surface area of small crystals, some of the concentrate is retained in the ice slurry after washing. This technique is preferred by the food processing industry where the concentrate is the desired product and the ice is the waste. A small amount of concentrate in the ice can be tolerated. In this application, the desired end product is the ice and the concentrate is the waste.

In progressive freezing, ice is grown on a refrigerated surface at a controlled rate. The impurities are rejected into the solution ahead of the growing ice front. When the impurities reach the point at which they are no longer rejected, the refrigeration cycle is stopped and the concentrate is drained away. Because of its operational simplicity, we believe that progressive freezing is the method of choice for this application. Taylor (1989) found that TNT and RDX were excluded from the ice structure at freezing rates of up to $3.2 \mathrm{~mm} /$ hr using this technique. Conceivably, progressive freezing could be accomplished by industrial ice-making machines such as the one shown in Figure 1. These machines can produce several tons of ice per day. For example, North Star Ice Equipment Corporation

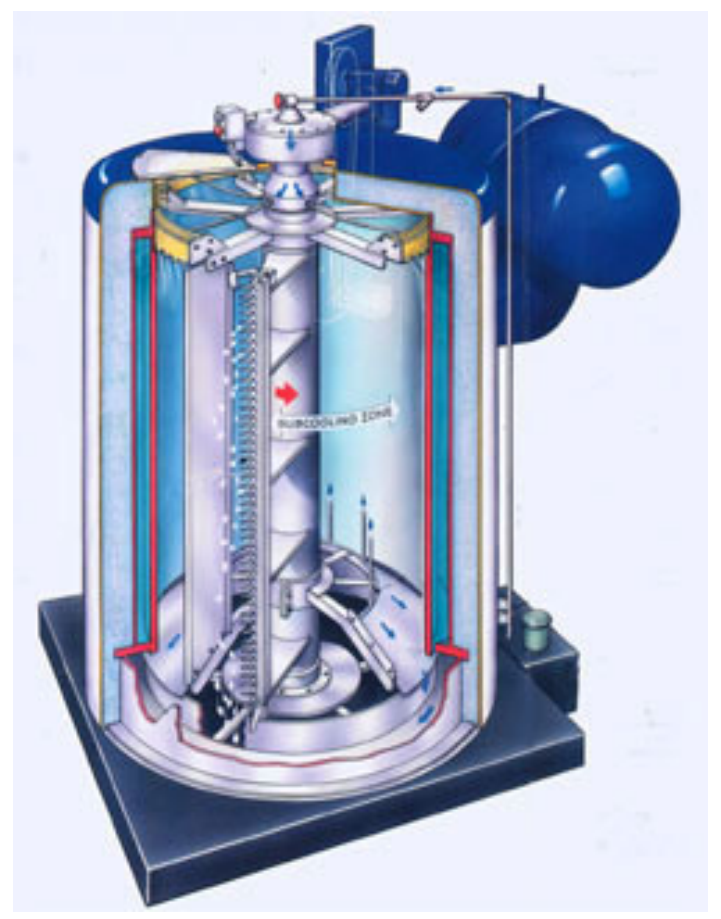

Figure 1. Drum ice maker. (Illustration courtesy of North Star.)

(Seattle, Washington) has a flake ice maker that can freeze up to $48,500 \mathrm{~L} /$ day.

\section{Objective}

The overall purpose of this study is to evaluate the feasibility of using progressive freeze concentration to dewater pinkwater, a typical Army industrial waste. Specific objectives of this project are to

1. Measure and model the effect of freezing rate, solute concentration, solute characteristics, and other variables on the mechanism of freeze concentration.

2. Measure the quality of the meltwater and concentrate.

3. Use the models to predict the best method of freezing and the best operational range for each variable.

\section{Scope}

Halde (1980) found that the effectiveness of the progressive freezing process depends on three variables: freezing rate, mixing intensity, and impurity concentration. The freezing rate is important because it affects ice crystal growth and the subsequent rejection of impurities. Generally, a slow freezing rate is more effective than a fast freezing rate. Mixing is important because it sweeps away the accumulation of impurities ahead of the freezing front. For this same 
reason, a solution containing a high concentration of impurities is more difficult to purify than the same solution containing a lower concentration of impurities. This study examines the effects of freezing rate and impurity concentration only. Mixing intensity was not studied because it is an artifact of the mechanical design and geometry of the freezing device.

To study the effects of freezing rate and impurity concentration, we built a bench-scale freeze concentrator (see Fig. 2). This device can freeze a sample at a predetermined constant freezing rate. To eliminate the force of gravity on the migration of particles away from the freezing front, a $30-\mathrm{cm}$-long by $5-\mathrm{cm}$-diameter Plexiglas tube is made to travel horizontally. A small reservoir located at the end of the tube is used to collect any excess pinkwater produced by the expansion of the sample during freezing. The temperature of the refrigerated collar at the entrance to the freezing chamber is adjusted to obtain different freezing rates.

\section{EXPERIMENTAL METHODS}

\section{Pinkwater}

The pinkwater was obtained from the equalization tank at the treatment facility located at McAlester Army Ammunition Plant (AAP) in McAlester, Oklahoma. Four 1-L samples were collected in brown glass bottles, refrigerated, packed in dry ice, and shipped to CRREL. The contents of these bottles were then mixed to obtain a homogeneous starting solution. We analyzed

\begin{tabular}{|c|c|c|c|c|}
\hline $\begin{array}{l}\text { Run } \\
\text { no }\end{array}$ & $\begin{array}{l}\text { Temperature } \\
\left({ }^{\circ} \mathrm{C}\right)\end{array}$ & $\begin{array}{l}\text { Freezing } \\
\text { time } \\
\text { (hr) }\end{array}$ & $\begin{array}{l}\text { Length of } \\
\text { ice cylinder } \\
\text { (cm) }\end{array}$ & $\begin{array}{l}\text { Freezing } \\
\text { rate } \\
(\mathrm{mm} / \mathrm{hr})\end{array}$ \\
\hline 1 & -24.1 & 19 & 22.3 & 11.7 \\
\hline 2 & -24.1 & 31 & 21.0 & 6.7 \\
\hline 3 & -15.0 & 65 & 25.0 & 3.8 \\
\hline 4 & -10.0 & 100 & 21.5 & 2.1 \\
\hline 5 & -20.0 & 26 & 24.5 & 9.4 \\
\hline 6 & -15.0 & 46.5 & 25.0 & 5.4 \\
\hline
\end{tabular}

several aliquots of this starting solution and found it to contain $22.6 \mathrm{mg} / \mathrm{L}$ TNT (2,4,6-trinitrotoluene); 12.0 mg/L RDX (hexahydro-1,3,5-trinitro-1,3,5-triazine); $1.5 \mathrm{mg} / \mathrm{L}$ HMX (octahydro-1,3,5,7-tetranitro-1,3,5,7tetrazocine); $1.9 \mathrm{mg} / \mathrm{L}$ TNB (1,3,5-trinitrobenzene); and the degradation products $0.7 \mathrm{mg} / \mathrm{L} 2-\mathrm{Am}-\mathrm{DNT}$ (2amino-4,6-dinitrotoluene) and $0.8 \mathrm{mg} / \mathrm{L} 4-\mathrm{Am}-\mathrm{DNT}$ (4-amino-2,6-dinitrotoluene).

\section{Freeze concentration experiments}

Six runs were conducted using the apparatus shown in Figure 2. The conditions during each run are listed in Table 1. After each run, the Plexiglas tube was removed from the apparatus and taken to a location where the ice cylinder could be removed, placed in a Ziploc bag, and stored in the freezer compartment of a conventional refrigerator. The concentrate was collected, poured into brown glass jars, and stored in the same refrigerator. The Plexiglas tube was then refilled with

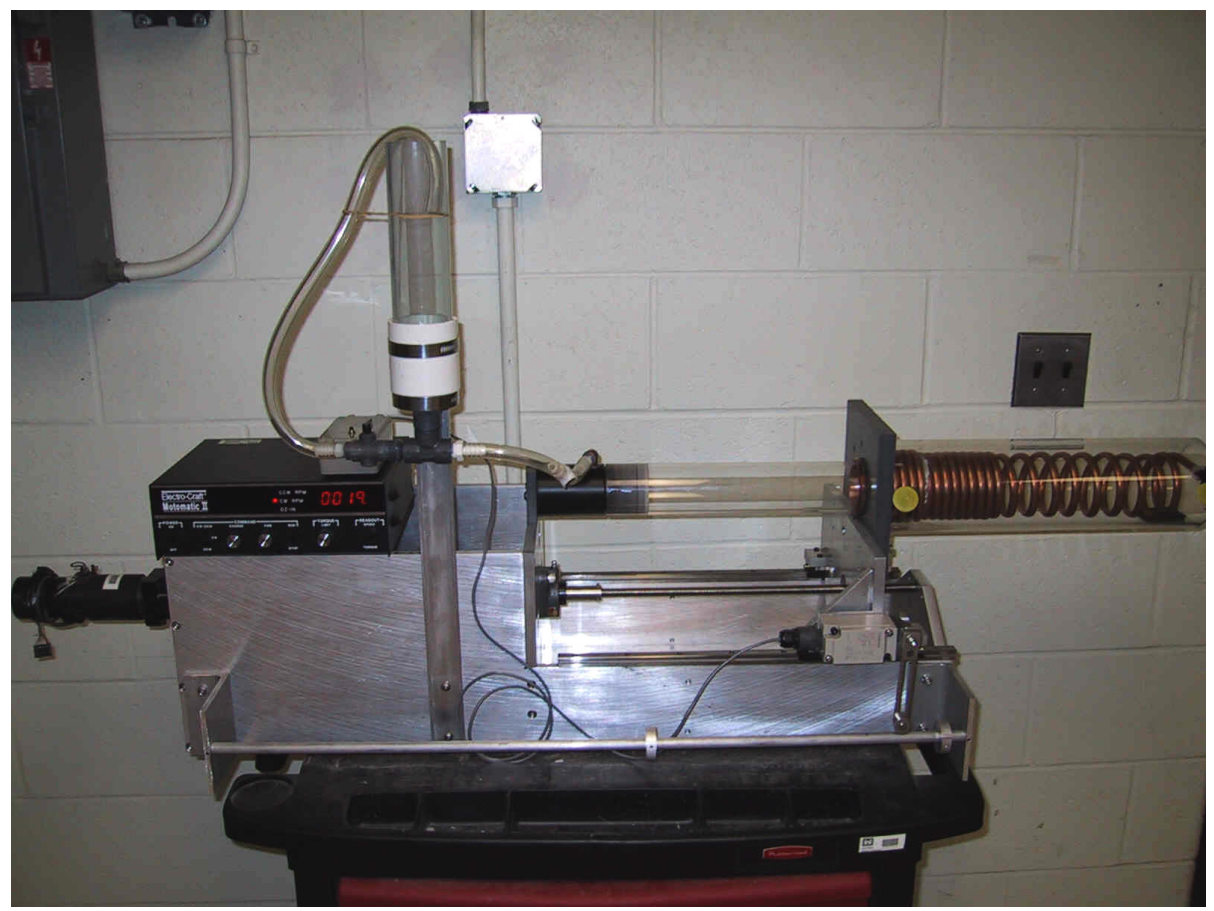

Figure 2. Bench-scale freeze concentrator. 
pinkwater and the experiment was repeated at a different freezing rate.

The ice cylinders were cut into disks (parallel to the freezing front) on a band saw located in a $-30^{\circ} \mathrm{C}$ coldroom. Each disk was about $2 \mathrm{~cm}$ thick and was placed in a previously weighed brown-glass, widemouthed jar, which was then reweighed to obtain the exact volume of melt. The ice was allowed to melt and the samples stored in a refrigerator until analyzed.

To determine whether or not explosives were exceeding their solubility limit and precipitating out of solution, we analyzed the water and the particles separately. To analyze the water, $4 \mathrm{~mL}$ of each sample were added to $1 \mathrm{~mL}$ of acetonitrile and the mixture filtered through a Millipore $0.45-\mu \mathrm{m}$ cartridge into $2-\mathrm{mL}$ autosample vials. To analyze the particles, the remaining water sample $(\sim 35 \mathrm{~mL})$ was filtered through an Alltech $0.45-\mu \mathrm{m}$ nylon membrane filter and the filter was then placed in a vial containing $10 \mathrm{~mL}$ of acetonitrile. The vials were shaken for 30 minutes and then allowed to sit in the dark for 48 hours. One $\mathrm{mL}$ of the acetonitrile was added to $4 \mathrm{~mL}$ of distilled water and the mixture filtered into autosample vials.

\section{RP-HPLC analysis}

Reverse-phase high-performance liquid chromatography (RP-HPLC) was used for these analyses. Method 8330 (EPA 1994), the standard method for determining explosive residues in water and soil, was followed. We used a C-18 column that allowed us to separate RDX, HMX, TNT, and their derivatives. Two commercially available standards, Mix 1 and Mix 2, which contained all the analytes of interest, were run with the samples. The eluent used was a mixture of distilled water and isopropyl alcohol in an 85:15 mix.

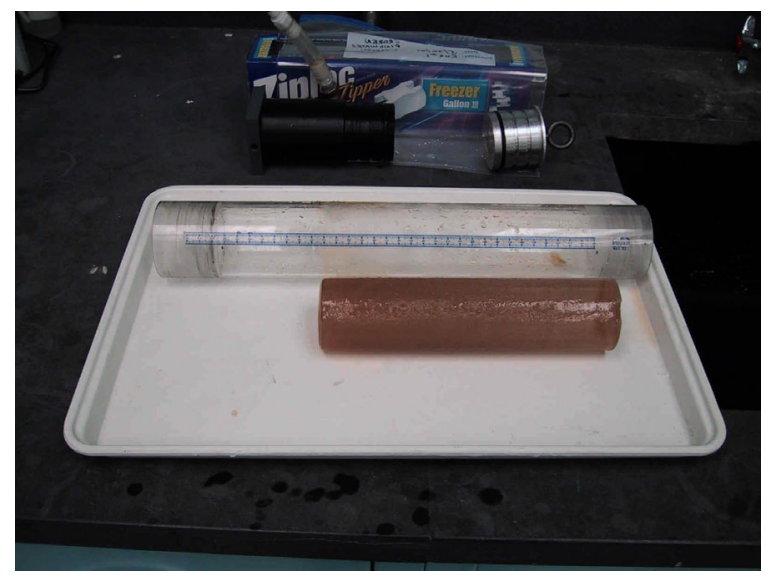

a. Ice cylinder produced during Run \#1.

\section{RESULTS}

Visual observations suggest that more contaminants were excluded at the slower freezing rates. Slow freezing rates produced a clearer ice cylinder than fast freezing rates. This can be seen in Figure 3 by comparing the color of the ice cylinders frozen in Runs \#1 and \#4. The ice cylinder produced during Run \#1, which was frozen at $11.7 \mathrm{~mm} / \mathrm{hr}$, is obviously darker than the cylinder produced during Run \#4, which was frozen at $2.1 \mathrm{~mm} / \mathrm{hr}$. Average TNT concentrations in the ice cylinders were $18.10 \mathrm{mg} / \mathrm{L}$ and $0.88 \mathrm{mg} / \mathrm{L}$ for Runs \#1 and \#4, respectively.

The initial pinkwater was cloudy, but no particles were visible. After freezing, the residue and some of the ice segments contained distinct particles. These varied from small, sub-millimeter, rounded particles in the samples nearest the freezing plate to millimetersized, elongated particles near the ice-water boundary. The ends of the cores in contact with the residual liquid were usually coated with precipitated material.

Chemical analyses of the ice cylinders confirmed the visual observations. More of each constituent was excluded from the ice cylinder as the freezing rate was decreased. The concentrations of TNT, RDX, HMX, TNB, 2-Am-DNT, and 4-Am-DNT in each ice cylinder are tabulated in Appendix A.

The effect of freeze concentration on TNT is shown in Figure 4. As expected, the TNT concentration was highest in the ice cylinder produced at the fastest freezing rate of $11.7 \mathrm{~mm} / \mathrm{hr}$. At $9.4 \mathrm{~mm} / \mathrm{hr}$, the TNT concentrations appear to be nearly the same as at $11.7 \mathrm{~mm} /$ $\mathrm{hr}$. The plots at 6.7 and $5.4 \mathrm{~mm} / \mathrm{hr}$ show a significant reduction in TNT concentration. The ice cylinders with the lowest TNT concentrations were produced at freez-

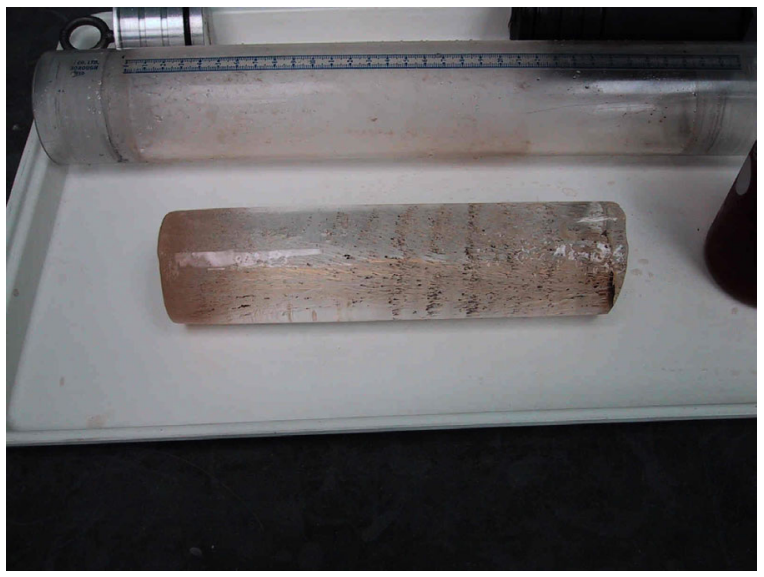

b. Ice cylinder produced during Run \#4.

Figure 3. Visual comparison of ice cylinder color and clarity. Freezing direction is left to right. 
ing rates of 3.8 and $2.1 \mathrm{~mm} / \mathrm{hr}$. The pattern is consistent with the mechanism of the freeze concentration process discussed earlier.

The plots in Figure 4 show that the TNT concentration in the ice cylinders varied according to freezing distance. For example, at the $6.7 \mathrm{~mm} / \mathrm{hr}$ freezing rate, the average TNT concentration in the first $2 \mathrm{~cm}$ of ice was $20.22 \mathrm{mg} / \mathrm{L}$. In the second $2 \mathrm{~cm}$ of ice (freezing distance $=4 \mathrm{~cm}$ ), the TNT concentration dropped to $11.01 \mathrm{mg} / \mathrm{L}$. From this point to a freezing distance of $16 \mathrm{~cm}$, the TNT concentration varied only slightly from $9.20 \mathrm{mg} / \mathrm{L}$ to $11.86 \mathrm{mg} / \mathrm{L}$. At $18 \mathrm{~cm}$, the TNT concentration jumped up to $14.76 \mathrm{mg} / \mathrm{L}$ and continued to climb to $15.52 \mathrm{mg} / \mathrm{L}$ at $20 \mathrm{~cm}$, and $18.03 \mathrm{mg} / \mathrm{L}$ at $22 \mathrm{~cm}$. The high concentration in the first segment can be explained by the fact that the freezing rate was probably faster near the aluminum end cap, which has a greater heat transfer capacity than ice. From $2 \mathrm{~cm}$ to $16 \mathrm{~cm}$, TNT inclusion was relatively constant, although the concentration of TNT in the residuals was increasing. Beyond $16 \mathrm{~cm}$, the TNT concentration in the residual ahead of the freezing front was too great to continue the rejection rate, and so more TNT was included in the ice cylinder. The higher concentration in the end segment was probably caused by the inclusion of rejected contaminants attached to the end of the segment.

The effect of freeze concentration on RDX is shown in Figure 5. The freeze concentration effect is similar

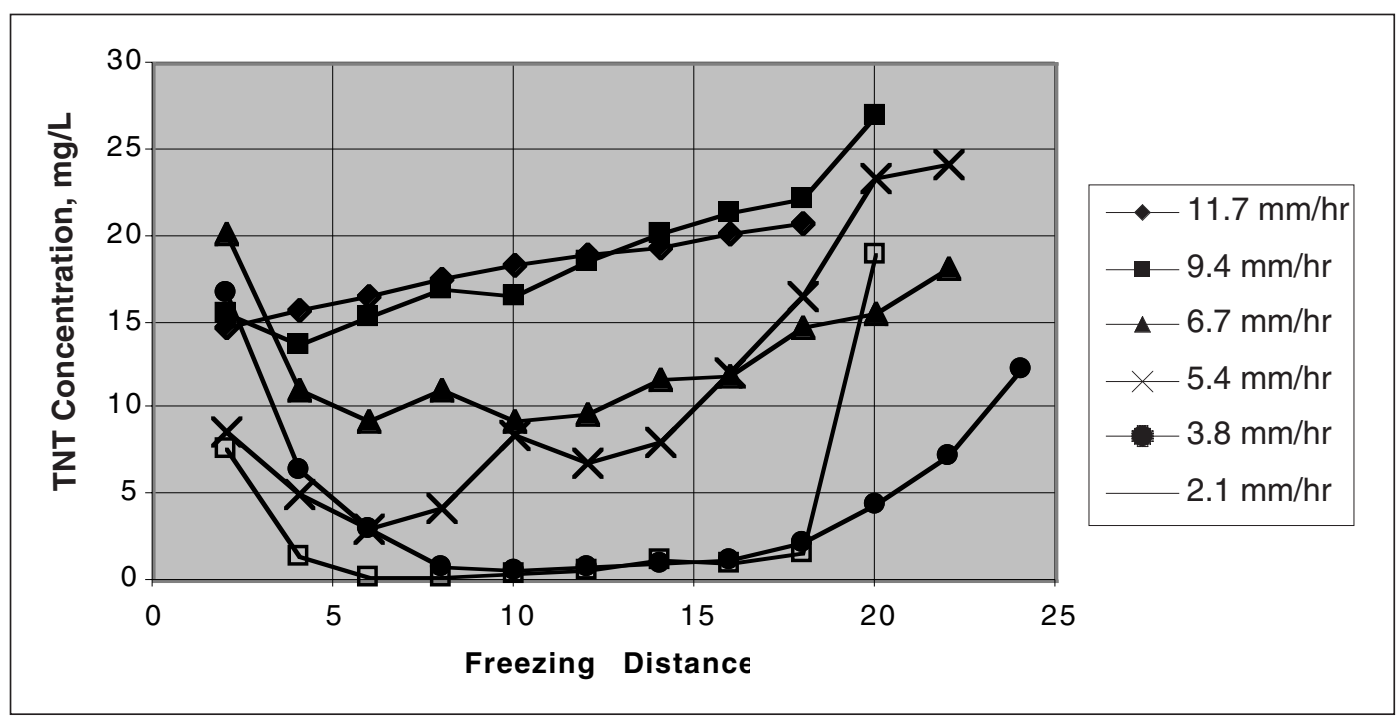

Figure 4. TNT concentration in ice cylinder at each freezing rate.

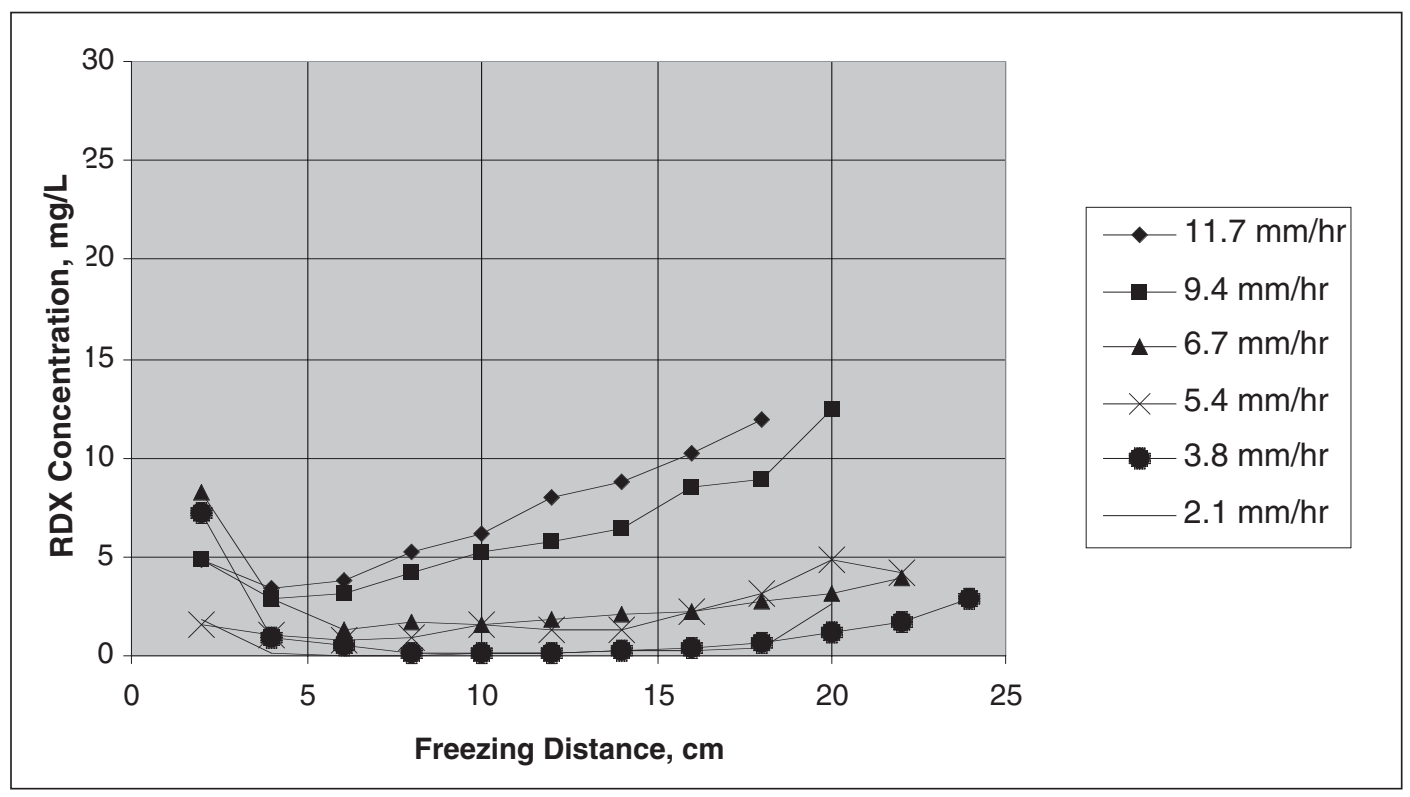

Figure 5. RDX concentration in ice cylinder at each freezing rate. 


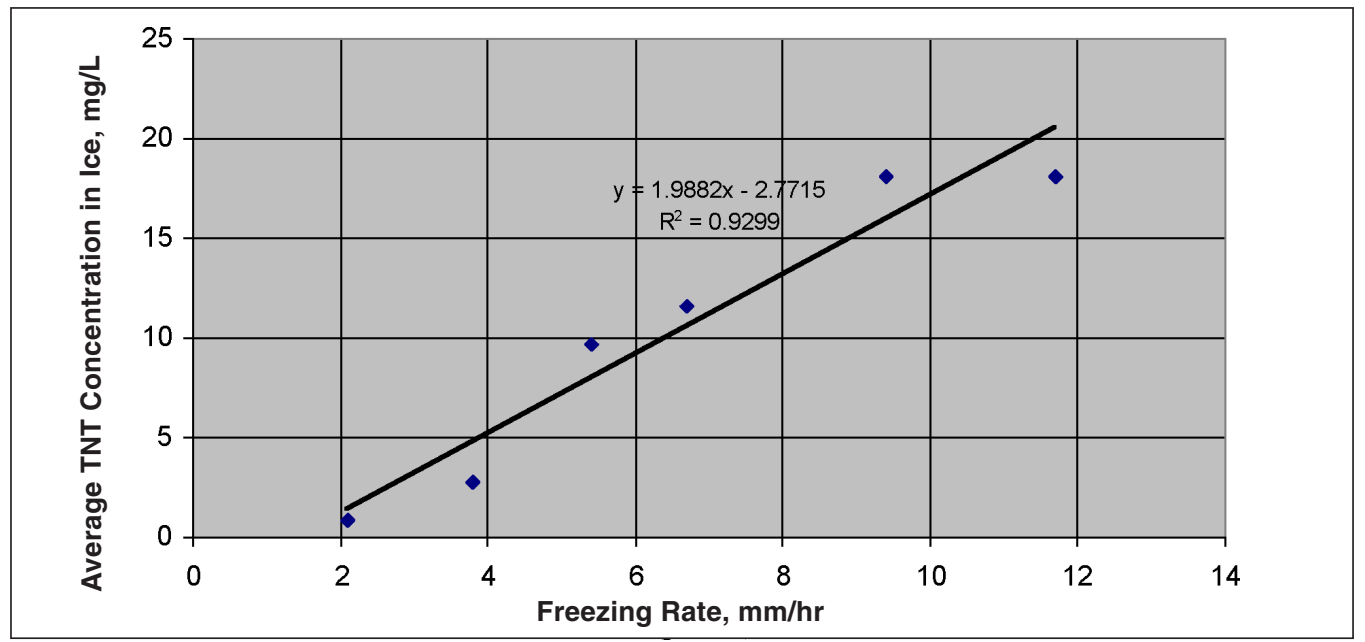

Figure 6. Effect of freezing rate on average TNT concentration in ice column.

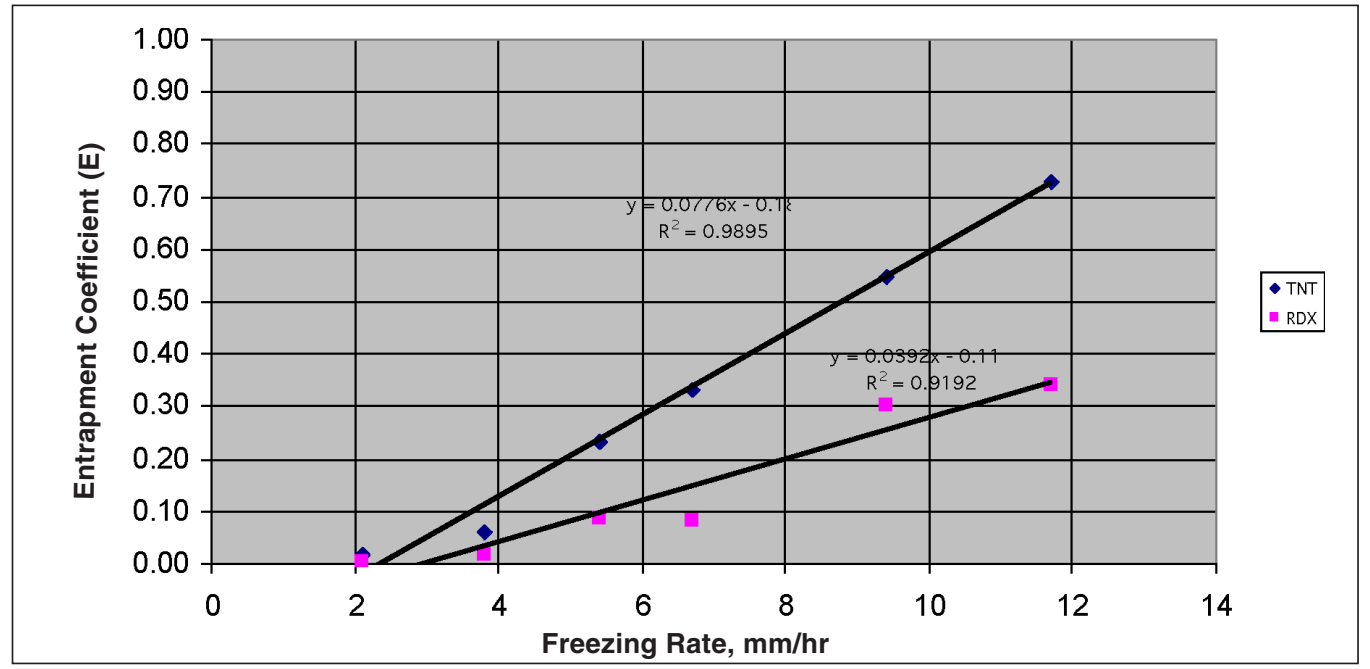

Figure 7. Entrapment coefficients for TNT and RDX as a function of freezing. rate.

to that observed for TNT. In this case, the pinkwater contained only $12.0 \mathrm{mg} / \mathrm{L}$ RDX, which is below the current MCAAP discharge limit of $15.0 \mathrm{mg} / \mathrm{L}$. Therefore the main treatment concern is TNT.

TNT and RDX concentrations in the residuals generally increased as the freezing rate decreased (see Table 2). This is consistent with the previous ice cylinder measurements, which showed that more TNT and RDX were being rejected at the lower freezing rates. There was a concern that freeze concentration would cause TNT and RDX to precipitate out and thus become an explosion hazard. However, that never happened because none of the residuals approached TNT or RDX saturation. According to Leggett (1985), the solubility limits for TNT and RDX are 130 and $42 \mathrm{mg} / \mathrm{L}$, respectively.

\section{DISCUSSION}

The results of these experiments show that freeze concentration can remove water (in the form of ice) from pinkwater. The quality of the meltwater depends on the freezing rate, as indicated earlier in Figures 4 and 5, and directly shown in Figure 6. According to the linear line of best fit, a freezing rate of $1.9 \mathrm{~mm} / \mathrm{hr}$ would be required to produce a meltwater with an average TNT concentration of $1.0 \mathrm{mg} / \mathrm{L}$, which is the discharge limit for McAlester AAP. The estimated fraction of $1.0 \mathrm{mg} / \mathrm{L}$ TNT meltwater produced by freeze concentration at a $1.9 \mathrm{~mm} / \mathrm{hr}$ freezing rate is 0.67 . This estimate is based on the data shown in Figure 4 where average TNT concentrations in the ice cylinder remain near $1.0 \mathrm{mg} / \mathrm{L}$ for $20 \mathrm{~cm}$, which is $67 \%$ of the pinkwater sample.

A freezing rate of $1.9 \mathrm{~mm} / \mathrm{hr}$ is much too slow for industrial ice-making equipment such as the ice maker shown in Figure 1. This equipment can freeze water at a rate of almost $270 \mathrm{~mm} / \mathrm{hr}$. It may be possible to slow the rate of freezing but the output would be drastically reduced. 


\begin{tabular}{|c|c|c|}
\hline \multicolumn{3}{|c|}{$\begin{array}{l}\text { Table 2. Concentrations of TNT and RDX in residu- } \\
\text { als. }\end{array}$} \\
\hline $\begin{array}{l}\text { Freezing rate } \\
(\mathrm{mm} / \mathrm{hr})\end{array}$ & $\begin{array}{l}\text { Residual } \\
\text { TNT conc. } \\
\text { (mg/L) }\end{array}$ & $\begin{array}{c}\text { Residual } \\
\text { RDX conc. } \\
\text { (mg/L) }\end{array}$ \\
\hline 11.7 & 24.7 & 19.16 \\
\hline 9.4 & 33.0 & 18.65 \\
\hline 6.7 & 34.7 & 26.34 \\
\hline 5.4 & 41.4 & 21.76 \\
\hline 3.8 & 46.1 & 38.74 \\
\hline 2.1 & 52.2 & 27.11 \\
\hline
\end{tabular}

Instead of trying to meet the $1.0 \mathrm{mg} / \mathrm{L}$ discharge limit in one freezing step, it may be possible to use several freezing steps at a high freezing rate until the desired meltwater quality is achieved. This approach is similar to the multi-stage distillation process used in desalination. In this case the number of freezing steps can be estimated from Figure 7, which is a plot of the entrapment coefficient versus the freezing rate. The entrapment coefficient (E) is defined as the adjusted mean concentration of TNT or RDX entrapped in the ice divided by the residual concentration. Based on the linear line of best fit to the TNT data, E is approximately 0.6 for a freezing rate of $10 \mathrm{~mm} / \mathrm{hr}$. This means that using the same initial TNT concentration as before $(22.6 \mathrm{mg} / \mathrm{L})$, it would take about six freezing steps at $10 \mathrm{~mm} / \mathrm{hr}$ to achieve $1.0 \mathrm{mg} / \mathrm{L} \mathrm{TNT}$ in the meltwater.

\section{CONCLUSION}

The results of this study show that the freeze concentration process is capable of meeting a $1.0 \mathrm{mg} / \mathrm{L}$ TNT discharge permit limit in the meltwater. However, the rate of freezing must be very slow to meet this criterion. An alternative would be to conduct multi-stage freezing at a higher freezing rate. Calculations show that the TNT limit could be achieved in six freezing cycles at $10 \mathrm{~mm} / \mathrm{hr}$. This approach may not be costeffective unless air conditioning can be produced as a by-product.

\section{LITERATURE CITED}

EPA (1994) Nitroaromatics and nitramines by HPLC. SW-846 Method 8330, Second update. Washington, DC: Environmental Protection Agency.

EPRI (1987) Industrial applications of freeze concentration technology. EPRI EM-5232, Project 2662-1. Palo Alto, California: Electric Power Research Institute.

Glen, J.W. (1974) The physics of ice. U.S. Army Cold Regions Research and Engineering Laboratory, CRREL Monograph II-C2A.

Halde, R. (1980) Concentration of impurities by progressive freezing. Water Research, 14(6): 575-580.

Integrated-Ice Systems, Inc. (1999) Ice-X Benefits. Integrated-Ice Systems, Inc., Woodinville, Washington (http://www.bio-radiant.com/IceBenefitsFR.html). Leggett, D.C. (1985) Sorption of military explosive contaminants on bentonite drilling muds. U.S. Army Cold Regions Research and Engineering Laboratory, CRREL Report 85-18.

Painter, D. (1996) Phytoremediation of TNT. The Military Engineer, 88(580): 45-46.

Taylor, S. (1989) Ice-water partition coefficients for RDX and TNT. U.S. Army Cold Regions Research and Engineering Laboratory, CRREL Report 89-8. 
APPENDIX A: FREEZE CONCENTRATION DATA

\begin{tabular}{|c|c|c|c|c|c|c|}
\hline & Tab & A1. TNT & reeze co & entratio & data. & \\
\hline & Run \#1 & Run \#2 & Run \#3 & Run \#4 & Run \#5 & Run \#6 \\
\hline & & & Tempera & $\mathrm{e},{ }^{\circ} \mathrm{C}$ & & \\
\hline & -24.1 & -24.1 & -15 & -10 & -20 & -15 \\
\hline & & & Freezing & te, $\mathrm{mm} / \mathrm{hr}$ & & \\
\hline & 11.7 & 6.7 & 3.8 & 2.1 & 9.4 & 5.4 \\
\hline $\begin{array}{l}\text { Length of } \\
\text { ice cylinder, } \mathrm{cm}\end{array}$ & & & TNT conc & tration, $\mathrm{ms}$ & & \\
\hline 2 & 14.77 & 20.22 & 16.74 & 7.57 & 15.44 & 8.65 \\
\hline 4 & 15.74 & 11.01 & 6.42 & 1.44 & 13.69 & 4.94 \\
\hline 6 & 16.55 & 9.24 & 3.05 & 0.29 & 15.34 & 2.94 \\
\hline 8 & 17.61 & 11.02 & 0.90 & 0.28 & 16.83 & 4.22 \\
\hline 10 & 18.30 & 9.20 & 0.58 & 0.47 & 16.52 & 8.49 \\
\hline 12 & 18.94 & 9.76 & 0.71 & 0.62 & 18.59 & 6.77 \\
\hline 14 & 19.38 & 11.67 & 0.92 & 1.26 & 20.19 & 8.00 \\
\hline 16 & 20.19 & 11.86 & 1.22 & 0.95 & 21.41 & 12.15 \\
\hline 18 & 20.68 & 14.76 & 2.20 & 1.70 & 22.25 & 16.52 \\
\hline 20 & & 15.52 & 4.46 & 18.92 & 26.99 & 23.29 \\
\hline 22 & & 18.03 & 7.17 & & & 24.10 \\
\hline 24 & & & 12.23 & & & \\
\hline 26 & & & & & & \\
\hline Mean & 18.02 & 12.94 & 4.72 & 3.35 & 18.73 & 10.92 \\
\hline Adj. mean* & 18.10 & 11.56 & 2.76 & 0.88 & 18.10 & 9.70 \\
\hline$\%$ Removal $^{\dagger}$ & 19.8 & 48.8 & 87.8 & 96.1 & 19.8 & 57.0 \\
\hline K & 0.73 & 0.33 & 0.06 & 0.02 & 0.55 & 0.23 \\
\hline Residual & 24.90 & 34.72 & 46.06 & 52.17 & 32.97 & 41.43 \\
\hline
\end{tabular}

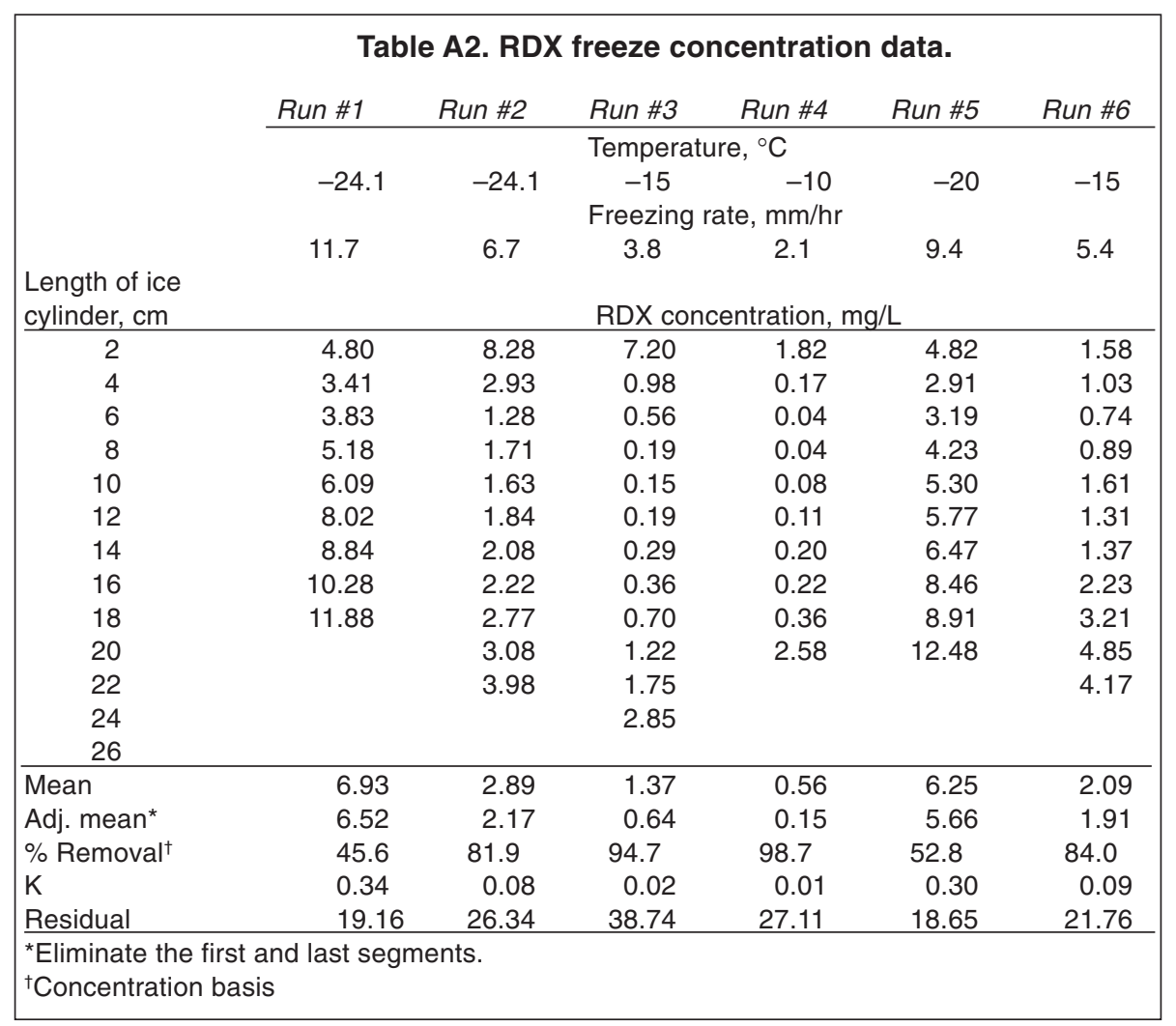




\begin{tabular}{|c|c|c|c|c|c|c|}
\hline & \multicolumn{6}{|c|}{ Table A3. HMX freeze concentration data. } \\
\hline & Run \#1 & Run \#2 & Run \#3 & Run \#4 & Run \#5 & Run \#6 \\
\hline & \multicolumn{6}{|c|}{ Temperature, ${ }^{\circ} \mathrm{C}$} \\
\hline & -24.1 & -24.1 & -15 & -10 & -20 & -15 \\
\hline & & & Freezing & e, $\mathrm{mm} / \mathrm{hr}$ & & \\
\hline & 11.7 & 6.7 & 3.8 & 2.1 & 9.4 & 5.4 \\
\hline $\begin{array}{l}\text { Length of ice } \\
\text { cylinder, cm }\end{array}$ & \multicolumn{6}{|c|}{$\mathrm{HMX}$ concentration, $\mathrm{mg} / \mathrm{L}$} \\
\hline 2 & 0.77 & 1.19 & 1.02 & 0.31 & 0.81 & 0.30 \\
\hline 4 & 0.73 & 0.53 & 0.23 & 0.04 & 0.57 & 0.18 \\
\hline 6 & 0.79 & 0.35 & 0.11 & 0.01 & 0.63 & 0.12 \\
\hline 8 & 0.89 & 0.41 & 0.06 & 0.01 & 0.73 & 0.15 \\
\hline 10 & 0.99 & 0.34 & 0.03 & 0.02 & 0.75 & 0.34 \\
\hline 12 & 1.13 & 0.38 & 0.04 & 0.03 & 0.88 & 0.24 \\
\hline 14 & 1.21 & 0.46 & 0.08 & 0.05 & 1.05 & 0.27 \\
\hline 16 & 1.26 & 0.47 & 0.07 & 0.05 & 1.36 & 0.47 \\
\hline 18 & 1.46 & 0.62 & 0.12 & 0.07 & 1.59 & 0.68 \\
\hline 20 & & 0.63 & 0.21 & 0.46 & 2.23 & 1.04 \\
\hline 22 & & 0.81 & 0.33 & & & 1.02 \\
\hline 24 & & & 0.57 & & & \\
\hline \multicolumn{7}{|l|}{26} \\
\hline Mean & 1.02 & 0.56 & 0.24 & 0.10 & 1.06 & 0.44 \\
\hline Adj. mean* & 1.00 & 0.47 & 0.13 & 0.03 & 0.95 & 0.39 \\
\hline$\%$ Removal $^{\dagger}$ & 34.6 & 69.5 & 91.7 & 97.8 & 38.2 & 74.7 \\
\hline $\mathrm{K}$ & 0.48 & 0.16 & 0.03 & 0.01 & 0.35 & 0.10 \\
\hline Residual & 2.10 & 2.97 & 4.72 & 3.95 & 2.71 & 3.85 \\
\hline \multicolumn{7}{|c|}{$\begin{array}{l}{ }^{*} \text { Eliminate the first and last segments. } \\
{ }^{\dagger} \text { Concentration basis }\end{array}$} \\
\hline
\end{tabular}

\begin{tabular}{|c|c|c|c|c|c|c|}
\hline & \multicolumn{6}{|c|}{ Table A4. TNB freeze concentration data. } \\
\hline & Run \#1 & Run \#2 & Run \#3 & Run \#4 & Run \#5 & Run \#6 \\
\hline & \multicolumn{6}{|c|}{ Temperature, ${ }^{\circ} \mathrm{C}$} \\
\hline & \multicolumn{6}{|c|}{ Freezing rate, $\mathrm{mm} / \mathrm{hr}$} \\
\hline & 11.7 & 6.7 & 3.8 & 2.1 & 9.4 & 5.4 \\
\hline $\begin{array}{l}\text { Length of ice } \\
\text { cylinder, } \mathrm{cm}\end{array}$ & \multicolumn{6}{|c|}{ TNB concentration, mg/L } \\
\hline 2 & 0.87 & 1.39 & 1.23 & 0.36 & 0.90 & 0.35 \\
\hline 4 & 0.75 & 0.60 & 0.24 & 0.05 & 0.61 & 0.22 \\
\hline 6 & 0.81 & 0.37 & 0.12 & 0.01 & 0.68 & 0.15 \\
\hline 8 & 0.98 & 0.48 & 0.05 & 0.01 & 0.81 & 0.20 \\
\hline 10 & 1.12 & 0.39 & 0.03 & 0.02 & 0.85 & 0.37 \\
\hline 12 & 1.35 & 0.44 & 0.03 & 0.02 & 1.01 & 0.32 \\
\hline 14 & 1.46 & 0.52 & 0.06 & 0.05 & 1.21 & 0.37 \\
\hline 16 & 1.65 & 0.53 & 0.06 & 0.04 & 1.40 & 0.57 \\
\hline 18 & 1.87 & 0.66 & 0.11 & 0.07 & 1.61 & 0.78 \\
\hline 20 & & 0.70 & 0.24 & 0.72 & 2.25 & 1.11 \\
\hline 22 & & 0.87 & 0.37 & & & 1.22 \\
\hline 24 & & & 0.64 & & & \\
\hline \multicolumn{7}{|l|}{26} \\
\hline Mean & 1.21 & 0.63 & 0.27 & 0.14 & 1.13 & 0.51 \\
\hline Adj. mean* & 1.16 & 0.52 & 0.13 & 0.03 & 1.02 & 0.45 \\
\hline$\%$ Removal $^{\dagger}$ & 37.9 & 72.1 & 92.9 & 98.2 & 45.4 & 75.7 \\
\hline $\mathrm{K}$ & 0.50 & 0.14 & 0.03 & 0.01 & 0.27 & 0.09 \\
\hline Residual & 2.34 & 3.72 & 4.80 & 4.65 & 3.73 & 4.88 \\
\hline
\end{tabular}




\begin{tabular}{|c|c|c|c|c|c|c|}
\hline \multicolumn{7}{|c|}{ Table A5. 2-Am freeze concentration data, mg/L. } \\
\hline \multirow{6}{*}{$\begin{array}{l}\text { Length of ice } \\
\text { cylinder, } \mathrm{cm}\end{array}$} & Run \#1 & Run \#2 & Run \#3 & Run \#4 & Run \#5 & Run \#6 \\
\hline & \multicolumn{6}{|c|}{ Temperature, ${ }^{\circ} \mathrm{C}$} \\
\hline & -24.1 & -24.1 & -15 & -10 & -20 & -15 \\
\hline & \multicolumn{6}{|c|}{ Freezing rate, $\mathrm{mm} / \mathrm{hr}$} \\
\hline & 11.7 & 6.7 & 3.8 & 2.1 & 9.4 & 5.4 \\
\hline & \multicolumn{6}{|c|}{ 2-Am concentration, $\mathrm{mg} / \mathrm{L}$} \\
\hline 2 & 0.37 & 0.52 & 0.44 & 0.08 & 0.19 & 0.09 \\
\hline 4 & 0.37 & 0.26 & 0.14 & 0.01 & 0.15 & 0.06 \\
\hline 6 & 0.40 & 0.19 & 0.06 & 0.00 & 0.17 & 0.04 \\
\hline 8 & 0.43 & 0.22 & 0.00 & 0.00 & 0.19 & 0.05 \\
\hline 10 & 0.47 & 0.19 & 0.02 & 0.01 & 0.19 & 0.09 \\
\hline 12 & 0.51 & 0.21 & 0.00 & 0.01 & 0.22 & 0.07 \\
\hline 14 & 0.53 & 0.23 & 0.00 & 0.02 & 0.25 & 0.08 \\
\hline 16 & 0.57 & 0.25 & 0.04 & 0.02 & 0.26 & 0.13 \\
\hline 18 & 0.61 & 0.31 & 0.00 & 0.02 & 0.29 & 0.18 \\
\hline 20 & & 0.34 & 0.12 & 0.17 & 0.37 & 0.26 \\
\hline 22 & & 0.40 & 0.18 & & & 0.29 \\
\hline 24 & & & 0.30 & & & \\
\hline \multicolumn{7}{|l|}{26} \\
\hline Mean & 0.47 & 0.28 & 0.11 & 0.03 & 0.23 & 0.12 \\
\hline Adj. mean* & 0.47 & 0.24 & 0.06 & 0.01 & 0.22 & 0.11 \\
\hline$\%$ Removal $^{\dagger}$ & 29.0 & 62.9 & 91.4 & 98.2 & 67.2 & 83.9 \\
\hline $\mathrm{K}$ & 0.57 & 0.22 & 0.03 & 0.01 & 0.38 & 0.13 \\
\hline Residual & 0.82 & 1.13 & 1.77 & 0.80 & 0.58 & 0.81 \\
\hline \multicolumn{7}{|c|}{$\begin{array}{l}{ }^{*} \text { Eliminate the first and last segments. } \\
{ }^{+} \text {Concentration basis }\end{array}$} \\
\hline
\end{tabular}

\begin{tabular}{|c|c|c|c|c|c|c|}
\hline & \multicolumn{6}{|c|}{ Table A6. 4-Am freeze concentration data. } \\
\hline \multirow{5}{*}{$\begin{array}{l}\text { Length of ice } \\
\text { cylinder, } \mathrm{cm}\end{array}$} & Run \#1 & Run \#2 & Run \#3 & Run \#4 & Run \#5 & Run \#6 \\
\hline & \multicolumn{6}{|c|}{ Temperature, ${ }^{\circ} \mathrm{C}$} \\
\hline & \multicolumn{5}{|c|}{ Freezing rate, $\mathrm{mm} / \mathrm{hr}$} & -15 \\
\hline & 11.7 & 6.7 & 3.8 & 2.1 & 9.4 & 5.4 \\
\hline & \multicolumn{6}{|c|}{ TNT concentration, mg/L } \\
\hline 2 & 0.44 & 0.58 & 0.51 & 0.11 & 0.22 & 0.13 \\
\hline 4 & 0.48 & 0.33 & 0.20 & 0.02 & 0.20 & 0.08 \\
\hline 6 & 0.51 & 0.28 & 0.09 & 0.00 & 0.23 & 0.05 \\
\hline 8 & 0.52 & 0.34 & 0.00 & 0.00 & 0.25 & 0.06 \\
\hline 10 & 0.56 & 0.26 & 0.02 & 0.01 & 0.25 & 0.12 \\
\hline 12 & 0.57 & 0.28 & 0.00 & 0.02 & 0.27 & 0.10 \\
\hline 14 & 0.59 & 0.32 & 0.00 & 0.03 & 0.30 & 0.12 \\
\hline 16 & 0.61 & 0.34 & 0.05 & 0.02 & 0.31 & 0.17 \\
\hline 18 & 0.62 & 0.42 & 0.00 & 0.03 & 0.32 & 0.25 \\
\hline 20 & & 0.46 & 0.16 & 0.25 & 0.38 & 0.36 \\
\hline 22 & & 0.53 & 0.24 & & & 0.38 \\
\hline 24 & & & 0.39 & & & \\
\hline \multicolumn{7}{|l|}{26} \\
\hline Mean & 0.54 & 0.38 & 0.14 & 0.05 & 0.27 & 0.17 \\
\hline Adj. mean* & 0.55 & 0.34 & 0.08 & 0.02 & 0.27 & 0.15 \\
\hline$\%$ Removal $^{\dagger}$ & 27.0 & 55.1 & 89.8 & 97.9 & 64.6 & 80.6 \\
\hline $\mathrm{K}$ & 0.62 & 0.29 & 0.04 & 0.02 & 0.48 & 0.18 \\
\hline Residual & 0.88 & 1.15 & 1.79 & 0.88 & 0.55 & 0.79 \\
\hline
\end{tabular}




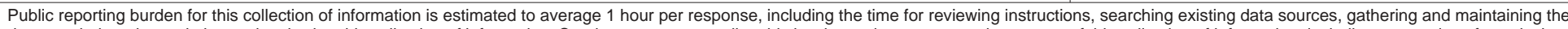

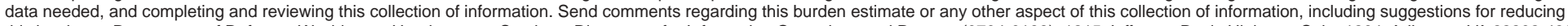

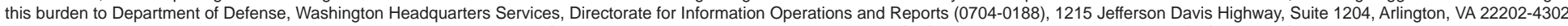

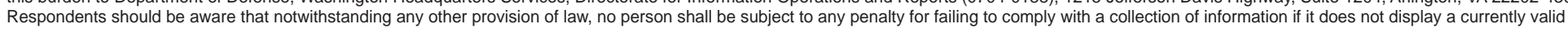
OMB control number. PLEASE DO NOT RETURN YOUR FORM TO THE ABOVE ADDRESS.
1. REPORT DATE (DD-MM-YY)
2. REPORT TYPE
3. DATES COVERED (From - To)

January 2002 Technical Report

4. TITLE AND SUBTITLE

5a. CONTRACT NUMBER

Freeze Concentration of Pinkwater

5b. GRANT NUMBER

5c. PROGRAM ELEMENT NUMBER

\section{AUTHOR(S)}

5d. PROJECT NUMBER

C. James Martel, Susan Taylor, and Stephen W. Maloney

5e. TASK NUMBER

5f. WORK UNIT NUMBER

7. PERFORMING ORGANIZATION NAME(S) AND ADDRESS(ES)

8. PERFORMING ORGANIZATION REPORT NUMBER

U.S. Army Engineer Research and Development Center

Cold Regions Research and Engineering Laboratory

72 Lyme Road

ERDC TR-02-1

Hanover, New Hampshire 03755-1290

9. SPONSORING/MONITORING AGENCY NAME(S) AND ADDRESS(ES)

10. SPONSOR / MONITOR'S ACRONYM(S)

Office of the Chief of Engineers

Washington, DC 20314

11. SPONSOR / MONITOR'S REPORT NUMBER(S)

\section{DISTRIBUTION / AVAILABILITY STATEMENT}

Approved for public release; distribution is unlimited.

Available from NTIS, Springfield, Virginia 22161.

\section{SUPPLEMENTARY NOTES}

\section{ABSTRACT}

The freeze concentration process was evaluated as a method of concentrating munitions wastes. A bench-scale study was conducted at the U.S. Army Cold Regions Research and Engineering Laboratory (CRREL) using pinkwater obtained from McAlester Army Ammunition Plant (AAP) in McAlester, Oklahoma. A special apparatus was constructed that allowed a sample to be frozen at a constant freezing rate. Six runs were conducted at different freezing rates. The results of this study show that the freeze concentration process is capable of meeting a $1.0 \mathrm{mg} / \mathrm{L}$ TNT discharge permit limit in the meltwater. However, the rate of freezing must be very slow to meet this criterion. An alternative would be to conduct multi-stage freezing at a higher freezing rate. Calculations show that the TNT limit could be achieved in six freezing cycles at $10 \mathrm{~mm} / \mathrm{hr}$.

15. SUBJECT TERMS
Freeze concentration
Pinkwater

Munitions waste

\begin{tabular}{|c|c|c|}
\hline a. REPORT & b. ABSTRACT & c. THIS PAGE \\
\hline $\mathrm{U}$ & $\mathrm{U}$ & $\mathrm{U}$ \\
\hline
\end{tabular}

17. LIMITATION OF OF ABSTRACT

$\mathrm{U}$
18. NUMBER OF PAGES

18 19a. NAME OF RESPONSIBLE PERSON

19b. TELEPHONE NUMBER (include area code) 


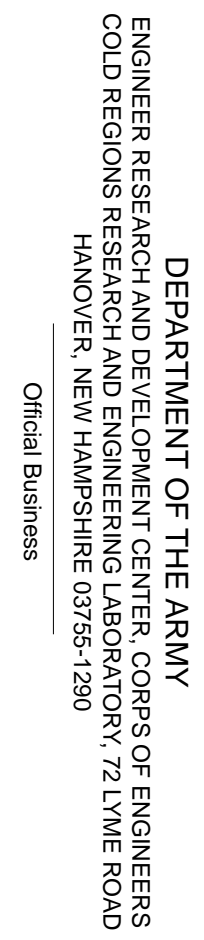

